\title{
Amycolatopsis saalfeldensis sp. nov., a novel actinomycete isolated from a medieval alum slate mine
}

Correspondence

Ingrid Groth

Ingrid.Groth@hki-jena.de

\author{
Marc René Carlsohn, ${ }^{1}$ Ingrid Groth, ${ }^{1}$ Geok Yuan Annie Tan, ${ }^{2}$ \\ Barbara Schütze, ${ }^{1}$ Hans-Peter Saluz, ${ }^{1}$ Thomas Munder, ${ }^{1} \dagger$ Jun Yang, ${ }^{3}$ \\ Joachim Wink ${ }^{4}$ and Michael Goodfellow ${ }^{5}$ \\ ${ }^{1}$ Leibniz-Institut für Naturstoff-Forschung und Infektionsbiologie eV, Hans-Knöll-Institut, \\ Beutenbergstrasse 11a, 07745 Jena, Germany \\ ${ }^{2}$ Division of Microbiology, Institute of Biological Sciences, Faculty of Science, University of \\ Malaya, 50603 Kuala Lumpur, Malaysia \\ ${ }^{3}$ Universität Tübingen, Biologisches Institut, Auf der Morgenstelle 28, 72076 Tübingen, \\ Germany \\ ${ }^{4}$ Sanofi-Aventis Deutschland GmbH, Industriepark Hoechst, 65926 Frankfurt (Main), Germany \\ ${ }^{5}$ Division of Biology, University of Newcastle, Newcastle upon Tyne NE1 7RU, UK
}

The genus Amycolatopsis is classified in the family Pseudonocardiaceae, suborder Pseudonocardineae (Stackebrandt et al., 1997). The genus currently contains 34 recognized species, most of which have been described in the past five years using polyphasic taxonomic approaches (Goodfellow et al., 2001; Labeda et al., 2003; Groth et al., 2007). Members of most of these species have been isolated from geographically diverse soils (Kim et al., 2002; SaintpierreBonaccio et al., 2005; Lee et al., 2006; Tan et al., 2006a), and others from clinical material (Labeda et al., 2003; Huang et al., 2004), vegetable matter (Goodfellow et al., 2001) and from the wall of a hypogean Roman catacomb (Groth et al., 2007).

tPresent address: CLONDIAG Chip Technologies GmbH, Löbstedter Strasse 103-105, 07749 Jena, Germany.

The GenBank/EMBL/DDBJ accession numbers for the $16 \mathrm{~S}$ rRNA gene sequences of strains HKI $0457^{\top}$, HKI 0473 and HKI 0474 are DQ792500, DO792501 and DO792502, respectively.

A dendrogram showing relationships between the isolates and between them and the type strains of closely related Amycolatopsis species based on MALDI-TOF MS data is available with the online version of this paper.
Amycolatopsis strains can be distinguished from members of other genera classified in the family Pseudonocardiaceae by using a combination of chemotaxonomic and morphological markers (Kim \& Goodfellow, 1999) and genus-specific oligonucleotide primers based on 16S rRNA gene sequences (Tan et al., 2006b). A range of phenotypic markers can be weighted to distinguish between species with validly published names (Saintpierre-Bonaccio et al., 2005; Lee et al., 2006; Groth et al., 2007). The present polyphasic study was designed to determine the taxonomic position of three strains which had been isolated from a medieval alum slate mine. The strains were assigned to the genus Amycolatopsis on the basis of their morphological properties and ability to produce the diagnostic amplification products when probed with the genus-specific $16 \mathrm{~S}$ rRNA oligonucleotide primers AMY2 (5'-GGTGTGGGCGACATCCACGTTGT- ${ }^{\prime}$ ) and ATOP (5'-GTATCGCAGCCCTCTGTACCAGC-3') as described by Tan et al. (2006b). The resultant data showed that the isolates represent a novel Amycolatopsis species for which the name Amycolatopsis saalfeldensis sp. nov. is proposed.

The three strains were isolated from the surfaces of acidic and heavy-metal-containing rocks of two galleries in the medieval alum slate mine Feengrotten in Saalfeld, Thuringia, 
Germany. Strain HKI $0457^{\mathrm{T}}$ was isolated from rock in the central grotto (second level of the mine) by touching it with a sterile cotton swab and dispersing adhering bacteria in $1 \mathrm{ml}$ sterile distilled water. Aliquots of the resultant suspension were spread over casein mineral agar plates (Altenburger et al., 1996), supplemented with cycloheximide $\left(50 \mu \mathrm{g} \mathrm{ml}^{-1}\right)$, and incubated at $28^{\circ} \mathrm{C}$ for 4 weeks. Strains HKI 0473 and HKI 0474 were isolated from rock surfaces towards the end of the Hess von Wichdorff Grotto (first level of the mine) by using the same procedure, but plating out onto humic acid agar (Hayakawa \& Nonomura, 1987).

Working cultures of the isolates were maintained on organic medium 79 agar (Prauser \& Falta, 1968). The cultures were preserved as mixtures of hyphae and fragmented spores in organic medium 79 broth and in glycerol medium (Groth et al., 2007) at $-80^{\circ} \mathrm{C}$. Stock cultures were also kept in liquid organic medium 79 supplemented with $5 \%$ DMSO in the vapour phase of liquid nitrogen. Biomass for the chemotaxonomic and molecular systematic studies was prepared by growing the isolates and Amycolatopsis kentuckyensis DSM $44652^{\mathrm{T}}$, Amycolatopsis lexingtonensis DSM $44653^{\mathrm{T}}$, A. mediterranei DSM $43304^{\mathrm{T}}$, Amycolatopsis pretoriensis DSM $44654^{\mathrm{T}}$, A. rifamycinica DSM $46095^{\mathrm{T}}$ and Amycolatopsis tolypomycina DSM $44544^{\mathrm{T}}$ in liquid organic medium 79 and bacto-tryptic soy broth (Sigma-Aldrich) for 24 to $48 \mathrm{~h}$ at $28^{\circ} \mathrm{C}$. For MALDI-TOF MS analysis the strains were cultivated as described by Groth et al. (2007).

Chromosomal DNA was extracted from the three isolates using slight modifications of the method of Pospiech \& Neumann (1995). PCR amplification of 16S rRNA genes was achieved using the conserved primers 27F ( $5^{\prime}$-AGAGTTTGATCCTGGCTCAG-3') and 1522R (5'-AAGGAGGTGATCCAGCCGCA-3') (Edwards et al., 1989) and the following conditions: initial denaturation at $95^{\circ} \mathrm{C}$ for 5 min, 35 cycles of $94{ }^{\circ} \mathrm{C}$ for $15 \mathrm{~s}, 55^{\circ} \mathrm{C}$ for $15 \mathrm{~s}, 72{ }^{\circ} \mathrm{C}$ for $1 \mathrm{~min}$; and a final extension for $10 \mathrm{~min}$ at $72^{\circ} \mathrm{C}$. After electrophoretic separation the 16S rRNA genes were extracted from the agarose gel using the MinElute Gel Extraction Kit (Qiagen), according to the manufacturer's instructions. Forward and reverse strands of amplified DNA fragments were directly sequenced using a Big Dye Terminator v. 3.1 Cycle Sequencing Kit and an ABI Prism 3100 sequencer (both Applied Biosystems).

The resultant 16S rRNA gene sequences were aligned manually using the PHYDIT program (http://plaza.snu.ac.kr/ $\sim$ jchun/phydit/), against corresponding sequences of representatives of the family Pseudonocardiaceae retrieved from the GenBank/EMBL/DDBJ databases. Unrooted phylogenetic trees were inferred using the least-squares (Fitch \& Margoliash, 1967), maximum-parsimony (Fitch, 1971) and neighbour-joining (Saitou \& Nei, 1987) treemaking algorithms. Evolutionary distance matrices were generated for the least-squares and neighbour-joining algorithms, using the method of Jukes \& Cantor (1969). All of the phylogenetic analyses were carried out using the
PHYLIP suite of programs (Felsenstein, 1993). The robustness of the resultant trees was evaluated by bootstrap analysis (Felsenstein, 1985) of neighbour-joining data based on 1000 resamplings using the TREECON program (Van de Peer \& De Wachter, 1994). The root position of the tree was estimated using Prauserella rugosa DSM $43194^{\mathrm{T}}$ (accession no. AF051342) as the outgroup organism.

Almost complete 16S rRNA gene sequences were generated for the three novel isolates (>1447 nt), all of which had identical sequences. Comparison of the $16 \mathrm{~S}$ rRNA gene sequences with corresponding sequences of representatives of the family Pseudonocardiaceae showed that the isolates belong to the genus Amycolatopsis (data not shown). The high 16S rRNA gene sequence similarities found between the isolates and representatives of the genus Amycolatopsis (94.3-98.4\%) support the addition of these strains to the genus.

It is apparent from Fig. 1 that the isolates are most closely associated with the A. mediterranei $16 \mathrm{~S}$ rRNA subclade, though this relationship is not supported by a high bootstrap value in the neighbour-joining analysis. Strain HKI $0457^{\mathrm{T}}$ was most closely related to A. rifamycinica DSM $46095^{\mathrm{T}}$. The two organisms shared a 16S rRNA gene sequence similarity of $98.4 \%$, a value that corresponded to 23 differences at 1432 locations. The isolates also shared relatively high $16 \mathrm{~S}$ rRNA gene sequence similarities with the type strains of $A$. kentuckyensis $(98.1 \%)$, A. lexingtonensis $(98.1 \%)$, A. mediterranei $(98.2 \%)$, A. pretoriensis (98.2\%) and A. tolypomycina (98.1\%). DNA-DNA relatedness studies were not carried out between isolate HKI $0457^{\mathrm{T}}$ and its closest phylogenetic neighbours, as it is known that the type strains of Amycolatopsis species classified in the A. mediterranei $16 \mathrm{~S}$ rRNA subclade share much higher $16 \mathrm{~S}$ rRNA gene similarities than those cited above but have lower DNA-DNA relatedness values (Labeda et al., 2003; Wink et al., 2003; Bala et al., 2004), that is, values well below the $70 \%$ cut-off point recommended for the delineation of genomic species (Wayne et al., 1987).

The isolates were examined for a range of key chemical markers to establish whether they had a chemotaxonomic profile typical of members of the genus Amycolatopsis. To this end, standard HPLC and TLC procedures were used to determine the isomers of diaminopimelic acid $\left(\mathrm{A}_{2} \mathrm{pm}\right)$ in whole-organism hydrolysates (Hasegawa et al., 1983), menaquinone profiles (Collins et al., 1977; Groth et al., 1996), muramic acid type (Uchida \& Aida, 1984), the presence of mycolic acids (Minnikin et al., 1975), predominant whole-organism sugars (Becker et al., 1965; Schön \& Groth, 2006) and polar lipid patterns (Minnikin et al., 1979; Collins \& Jones, 1980), using appropriate standards. All three isolates contained meso- $\mathrm{A}_{2} \mathrm{pm}$, arabinose and galactose in whole-organism hydrolysates (wall chemotype IV sensu; Lechevalier \& Lechevalier, 1970) together with glucose, mannose and rhamnose, $N$-acetylated muramic acid, diphosphatidylglycerol, phosphatidylethanolamine, hydroxyphosphatidylethanolamine, phosphatidylglycerol, 


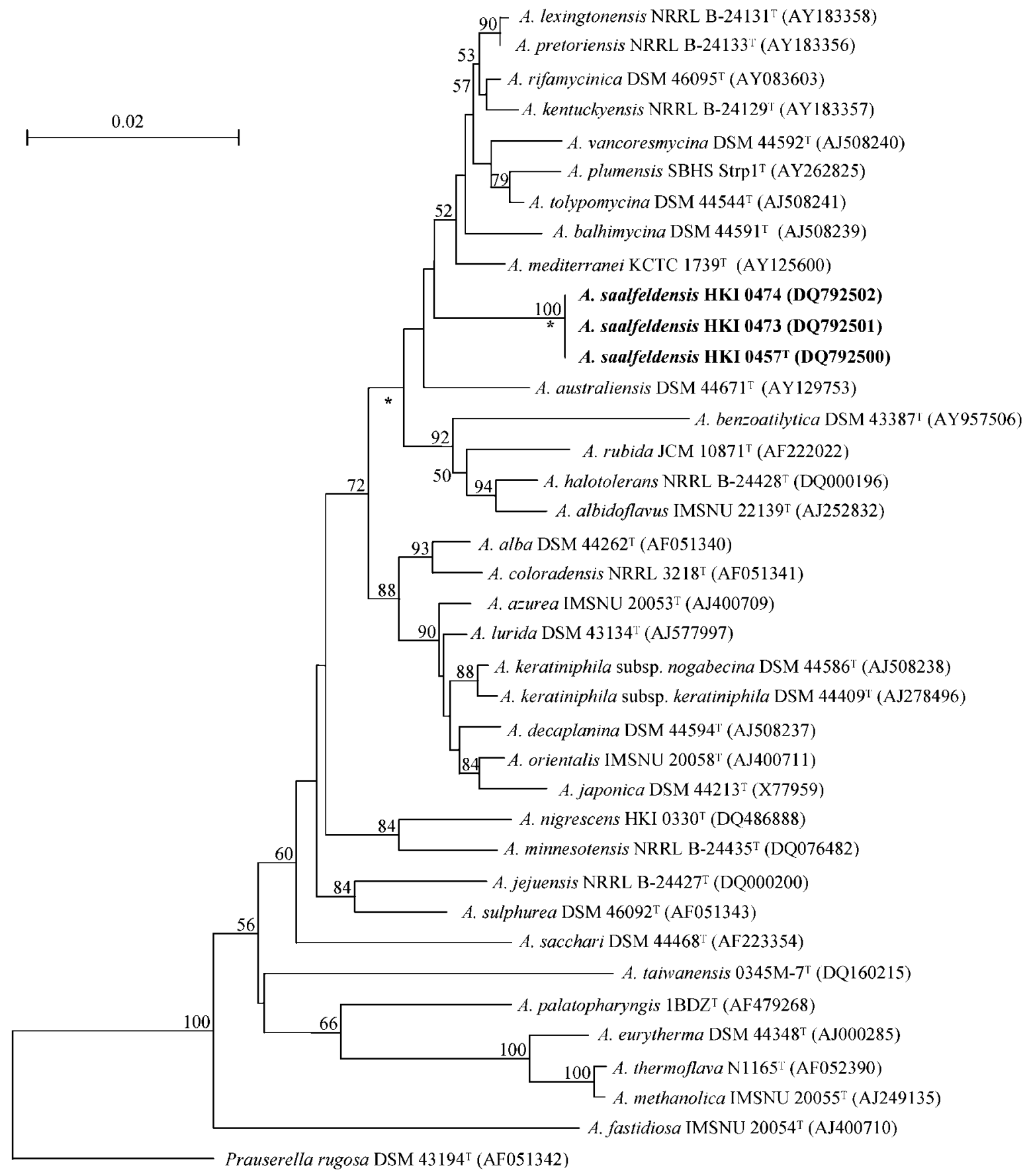

Fig. 1. Neighbour-joining tree based on nearly complete 16S rRNA gene sequences showing relationships between isolates HKI $0457^{\top}$, HKI 0473 and HKI 0474 and between them and representatives of the genus Amycolatopsis. Asterisks indicate branches of the tree that were also found using the least-squares and maximum-parsimony tree-making algorithms. The numbers at the nodes indicate the level of bootstrap support (\%) based on a neighbour-joining analysis of 1000 resampled datasets; only values above $50 \%$ are shown. Bar, 2 substitutions per 100 nt.

phosphatidylinositol, phosphatidylserine and two uncharacterized glycolipids (phospholipid pattern 2 sensu Lechevalier et al., 1977), and tetrahydrogenated menaquinones with nine isoprene units $\left[\mathrm{MK}-9\left(\mathrm{H}_{4}\right)\right]$ as the major isoprenologue ( $86-88 \%$ of total) with minor proportions of MK- $8\left(\mathrm{H}_{4}\right)(4-5 \%)$, MK-9 $\left(\mathrm{H}_{6}\right)(1-3 \%)$ and MK-10 $\left(\mathrm{H}_{4}\right)$ $(2 \%)$, but they lacked mycolic acids. These data serve to distinguish the isolates from all other wall chemotype IV 
actinomycetes, apart from those classified in the genus Amycolatopsis (Lechevalier et al., 1986; Kim \& Goodfellow, 1999; Takahashi, 2001).

The fatty acid profiles of the isolates grown in bacto-tryptic soy broth for $48 \mathrm{~h}$ were determined using the MIDI system (www.midi-inc.com/). All of the strains had a very similar fatty acid composition in which 14-methylpentadecanoic acid (iso- $\mathrm{C}_{16: 0}$ ) was the major component $(41-42 \%$ of total); the fatty acids found in smaller proportions were iso- $\mathrm{C}_{17: 0}(8-10 \%)$, iso- $\mathrm{C}_{15: 0}(8-9 \%)$, iso- $\mathrm{C}_{14: 0}(7-9 \%)$, iso- $2 \mathrm{OH} \mathrm{C} \mathrm{C}_{16: 0}(4-6 \%), \mathrm{C}_{15: 0}(6 \%)$ and $\mathrm{C}_{17: 0}(5-7 \%)$. These profiles are similar to those recorded for members of established Amycolatopsis species (Yassin et al., 1993; Wink et al., 2004; Groth et al., 2007).

Morphological properties of the isolates were examined following growth on ISP media 2 and 3 agar plates (Difco; Shirling \& Gottlieb, 1966) at $28^{\circ} \mathrm{C}$ for up to 21 days. The $\mathrm{pH}$ growth range was established using shake flasks of liquid organic medium 79 , adjusted to $\mathrm{pH}$ values between 4.5 and 10.0 with either $1 \mathrm{M} \mathrm{HCl}$ or $20 \%$, (w/v) $\mathrm{Na}_{2} \mathrm{CO}_{3}$ solution, and incubated for 6 days at $28^{\circ} \mathrm{C}$. The isolates were also tested for their ability to grow on solidified minimal medium (Amoroso et al., 2000) supplemented with $\mathrm{CuSO}_{4}(2 \mathrm{mM}$ ) and $\mathrm{NiCl}_{2}(5 \mathrm{mM})$, respectively, following growth at $28^{\circ} \mathrm{C}$ for 21 days. The remaining physiological tests, including the determination of antibiotic sensitivity and enzymic activities, were carried out as described by Groth et al. (2003). The isolates formed an extensively branched substrate mycelium on the ISP media tested and moderate amounts of aerial hyphae only on ISP medium 3. Substrate and aerial hyphae fragmented into rod-like elements typical of Amycolatopsis strains. The strains also grew in the presence of copper and nickel salts, and shared a broad range of phenotypic properties. Some of the latter can be used to distinguish the isolates from the type strains of phylogenetically close Amycolatopsis species classified in the Amycolatopsis $16 \mathrm{~S}$ rRNA gene clade (Table 1).

UP-PCR reactions were performed on the three isolates and their phylogenetically closest neighbours using the primers AS4/AS15 of Bulat et al. (2000). The reactions were prepared in a final volume of $10 \mu \mathrm{l}$ containing $0.5 \mathrm{U}$ GoTaq (Promega), the GoTaq flexi buffer, $0.2 \mathrm{mM}$ of each of the four dNTPs, $3 \mathrm{mM} \mathrm{MgCl}, 1 \mu \mathrm{M}$ primer AS4, $2 \mu \mathrm{M}$ primer AS15 and about 20 ng extracted DNA. For initial calculation of $T_{\mathrm{m}}$ and primer concentration, the biomath $T_{\mathrm{m}}$-calculator provided by Promega was used (www.promega.com/ biomath/calc11.htm). The different primer concentrations were empirically optimized to give the best possible size range and distribution of the resulting bands. Amplifications were performed three times using Thermo-Fast low profile PCR plates (ABgene) in an MJ research PTC 225 thermal cycler according to the following profile: an initial step at $94^{\circ} \mathrm{C}$ for $2 \mathrm{~min}, 57^{\circ} \mathrm{C}$ for $40 \mathrm{~s}$ and $72{ }^{\circ} \mathrm{C}$ for $30 \mathrm{~s}$ to

Table 1. Physiological properties that separate the novel isolates from the type strains of phylogenetically close Amycolatopsis species

Strains: 1, A. saalfeldensis sp. nov. HKI $0457^{\mathrm{T}}$, HKI 0473 and HKI 0474; 2, A. mediterranei DSM $43304^{\mathrm{T}}$; 3, A. pretoriensis DSM $44654^{\mathrm{T}}$; 4, A. rifamycinica DSM $46095^{\mathrm{T}}$. Data for the hypoxanthine and xanthine tests for the reference strains were taken from Wink et al. (2003), Lechevalier et al. (1986) and Labeda et al. (2003). +, Positive; -, negative; W, weakly positive; ${ }^{\star}$, delayed reaction.

\begin{tabular}{|c|c|c|c|c|}
\hline Characteristic & 1 & 2 & 3 & 4 \\
\hline Colour of aerial mycelium & White & Absent & White to orange & White to orange \\
\hline Production of soluble pigment & - & - & $+($ faint $)$ & Light pale brown-yellow \\
\hline \multicolumn{5}{|l|}{ Decomposition of: } \\
\hline Hypoxanthine & - & + & + & + \\
\hline Xanthine & + & - & - & - \\
\hline Production of indole & - & + & - & - \\
\hline \multicolumn{5}{|l|}{ Growth on sole carbon sources: } \\
\hline Malate $(0.2 \%, \mathrm{w} / \mathrm{v})$ & + & + & - & + \\
\hline D-Raffinose $(1 \%$, w/v $)$ & - & + & + & + \\
\hline \multicolumn{5}{|l|}{ API ZYM tests: } \\
\hline Cystine arylamidase & - & + & + & + \\
\hline$\alpha$-Fucosidase & - & + & - & - \\
\hline$\beta$-Galactosidase & - & + & + & + \\
\hline$\beta$-Glucosidase & $\mathrm{W}$ & + & - & + \\
\hline Valine arylamidase & + & + & - & + \\
\hline \multicolumn{5}{|l|}{ Growth at: } \\
\hline $10^{\circ} \mathrm{C}$ & $\mathrm{W}^{*}$ & + & - & + \\
\hline $42^{\circ} \mathrm{C}$ & - & + & + & + \\
\hline
\end{tabular}


provide templates, followed by 30 cycles at $92{ }^{\circ} \mathrm{C}$ for $20 \mathrm{~s}, 57^{\circ} \mathrm{C}$ for $40 \mathrm{~s}, 72^{\circ} \mathrm{C}$ for $30 \mathrm{~s}$ and a final extension at $72^{\circ} \mathrm{C}$ for $2 \mathrm{~min}$. Amplification products were separated by gel electrophoresis in native polyacrylamide gels $(8 \%)$ containing $0.5 \%$ TBE buffer. Gels were stained with SYBR Safe (Invitrogen). Fingerprints were analysed using GelComparII software (version 4.5, Applied Maths). The banding patterns were automatically matched (optimization value $1 \%$, position tolerance value $0.4 \%$ ). This computed matching was refined manually afterwards. A phylogenetic clustering of the banding patterns was achieved using the built-in maximum-parsimony tree-making algorithm (Fitch, 1971). The topology of the resulting tree (Fig. 2) was evaluated by bootstrap analysis (Felsenstein, 1985) based on 1000 resamplings. It is clear from Fig. 2 that the isolates gave almost identical UP-PCR fingerprint patterns which serve to distinguish them from corresponding patterns of their closest phylogenetic neighbours.

For MALDI-TOF mass spectrometry, biomass of the isolates taken from cellulose acetate filters was examined as described previously (Kroppenstedt et al., 2005; Groth et al., 2007) using a Voyager mass spectrometer. The resultant spectra were added to an existing Amycolatopsis dataset, and the data were analysed using Data Explorer software (Applied Biosystems) and the peak lists compared using SARAMIS software (Anagnos Tec). It is evident from our results (supplementary Fig. S1 available with the online version of this paper) that the isolates have similar profiles that distinguish them from those of Amycolatopsis type strains, including those representing phylogenetically close taxa.

It is evident from the genotypic and phenotypic data that isolates HKI $0457^{\mathrm{T}}$, HKI 0473 and HKI 0474 form a homogeneous taxon that can be distinguished readily from representatives of phylogenetically close Amycolatopsis species classified in the A. mediterranei 16S rRNA gene clade. It is, therefore, proposed that the isolates be classified in the genus Amycolatopsis as Amycolatopsis saalfeldensis sp. nov.

\section{Description of Amycolatopsis saalfeldensis sp. nov.}

Amycolatopsis saalfeldensis (saal.feld.en'sis. N.L. fem. adj. saalfeldensis from Saalfeld, named after the place of origin, a town in Thuringia, Germany).

Aerobic, Gram-positive, non-acid/alcohol-fast, non-motile, catalase-positive actinomycete which forms an extensively branched vegetative mycelium (hyphal diameter 0.5$0.6 \mu \mathrm{m})$ that fragments into squarish rod-like elements. The substrate mycelium carries moderate amounts of white aerial hyphae which fragment into squarish rod-like elements. Diffusible pigments are not produced. Good growth occurs between 20 and $35^{\circ} \mathrm{C}$, but growth is not evident below 10 or at $42^{\circ} \mathrm{C}$. Grows well between $\mathrm{pH} 4.5$ and 8.0 and in the presence of $2 \%(\mathrm{w} / \mathrm{v}) \mathrm{NaCl}$, but does not grow at $\mathrm{pH} 9.0$ or in the presence of $4 \%(\mathrm{w} / \mathrm{v}) \mathrm{NaCl}$. Grows on minimal medium supplemented with $\mathrm{NiCl}_{2}(5 \mathrm{mM})$ and $\mathrm{CuSO}_{4}(2 \mathrm{mM})$, respectively. Oxidase is produced, aesculin and urea hydrolysed, and $\mathrm{H}_{2} \mathrm{~S}$ produced. Nitrate is not reduced to nitrite. Degrades casein, gelatin, hippurate, Tween 80 and tyrosine, but not adenine or potato starch. L-Arabinose, D-fructose, D-glucose, meso-inositol, D-mannitol, L-rhamnose (type strain weakly), sucrose and D-xylose are used as sole carbon sources for energy and growth, but not cellulose (all at 1\%,w/v). Similarly, acetate, aconitate, benzoate (weakly), citrate and succinate are used as sole carbon and energy sources for growth, but not DL-tartrate (all at $0.2 \%, w / v)$. Produces $\alpha$-chymotrypsin (weakly), leucine arylamidase, esterase (C4), esterase lipase (C8), $N$-acetyl- $\beta$-glucosamidase, $\alpha$-glucosidase, naphthhol-ASBI-phosphohydrolase, acid phosphatase and alkaline phosphatase, but not $\alpha$-galactosidase, $\beta$-glucuronidase, lipase (C14), $\alpha$-mannosidase or trypsin (API ZYM tests). Susceptible to chloramphenicol (30 $\mu \mathrm{g}$ per disc), ciprofloxacin ( $5 \mu \mathrm{g}$ per disc, weakly), imipenem (10 $\mu \mathrm{g}$ per disc), kanamycin sulphate (30 $\mu \mathrm{g}$ per disc), lincomycin hydrochloride ( $2 \mu \mathrm{g}$ per disc, weakly), ofloxacin (10 $\mu \mathrm{g}$ per disc, weakly), oxytetracycline hydrochloride (30 $\mu \mathrm{g}$ per disc), rifampicin (30 $\mu \mathrm{g}$ per disc), streptomycin sulfate $(10 \mu \mathrm{g}$ per disc) and
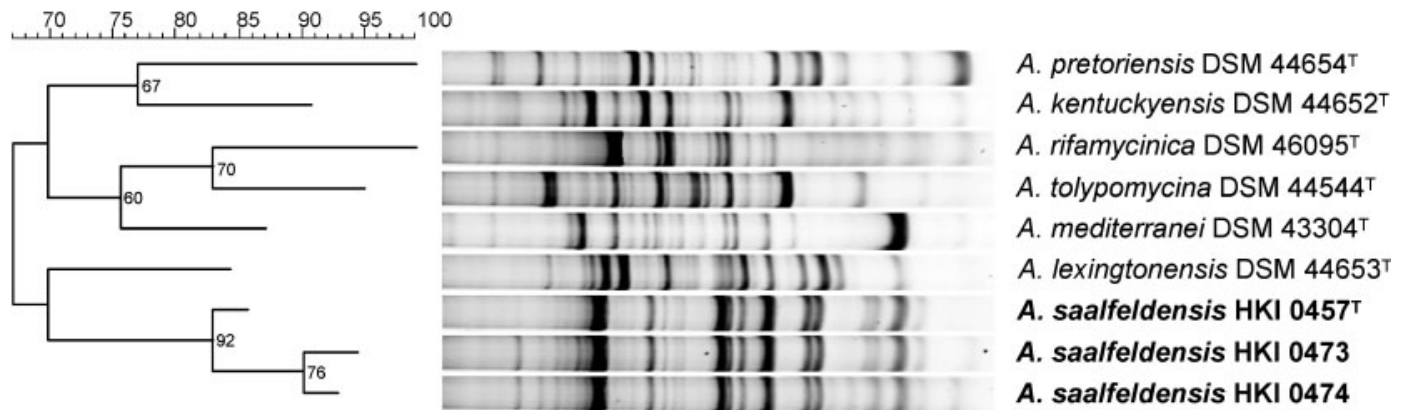

Fig. 2. Maximum-parsimony tree based on UP-PCR generated fingerprint data showing relationships between the isolates and between them and type strains of closely related Amycolatopsis species. Bootstrap rates (\%) at the nodes are based on 1000 resamplings; only values above $50 \%$ are shown. 
vancomycin hydrochloride ( $30 \mu \mathrm{g}$ per disc), but is resistant to ampicillin $(10 \mu \mathrm{g}$ per disc), methicillin (5 $\mu \mathrm{g}$ per disc), norfloxacin $(10 \mu \mathrm{g}$ per disc), novobiocin $(5 \mu \mathrm{g}$ per disc), penicillin G (10 IU per disc) and polymyxin B (300 IU per disc). Additional phenotypic properties are shown in Table 1. Chemotaxonomic characters are typical for Amycolatopsis species.

The type strain, HKI $0457^{\mathrm{T}}\left(=\mathrm{DSM} 44493^{\mathrm{T}}=\right.$ NRRL B$\left.24474^{\mathrm{T}}\right)$, was isolated from the surface of rocks in a medieval alum slate mine.

\section{Acknowledgements}

The authors are grateful to Carmen Schult and Christiane Weigel for excellent technical assistance and to Bernd Lochner (Saalfelder Feengrotten und Tourismus $\mathrm{GmbH}$ ) for his support in the sampling campaigns.

\section{References}

Altenburger, P., Kämpfer, P., Makristathis, A., Lubitz, W. \& Busse, H.-J. (1996). Classification of bacteria isolated from a medieval wall painting. J Biotechnol 47, 39-52.

Amoroso, M.-J., Schubert, D., Mitscherlich, P., Schumann, P. \& Kothe, E. (2000). Evidence for high affinity nickel transporter genes in heavy metal resistant Streptomyces spec. J Basic Microbiol 40, 295-301.

Bala, S., Khanna, R., Dadhwal, M., Prabagaran, S. R., Shivaji, S., Cullum, J. \& Lal, R. (2004). Reclassification of Amycolatopsis mediterranei DSM 46095 as Amycolatopsis rifamycinica sp. nov. Int J Syst Evol Microbiol 54, 1145-1149.

Becker, B., Lechevalier, M. P. \& Lechevalier, H. A. (1965). Chemical composition of cell-wall preparations from strains of various formgenera of aerobic actinomycetes. Appl Microbiol 13, 236-243.

Bulat, S. A., Lübeck, M., Alekhina, I. A., Funck-Jensen, D., Knudsen, I. M. B. \& Stephensen-Lübeck, P. (2000). Identification of a universally primed-PCR-derived sequence-characterized amplified region marker for an antagonistic strain of Clonostachys rosea and development of a strain-specific PCR detection assay. Appl Environ Microbiol 66, 4758-4763.

Collins, M. D. \& Jones, D. (1980). Lipids in the classification and identification of coryneform bacteria containing peptidoglycans based on 2,4-diaminobutyric acid. J Appl Bacteriol 48, 459-470.

Collins, M. D., Pirouz, T., Goodfellow, M. \& Minnikin, D. E. (1977). Distribution of menaquinones in actinomycetes and corynebacteria. J Gen Microbiol 100, 221-230.

Edwards, U., Rogall, T., Blöcker, H., Emde, M. \& Böttger, E. C. (1989). Isolation and direct complete nucleotide determination of entire genes. Characterization of a gene coding for 16S ribosomal RNA. Nucleic Acids Res 17, 7843-7853.

Felsenstein, J. (1985). Confidence limits on phylogenies: an approach using the bootstrap. Evolution 39, 783-791.

Felsenstein, J. (1993). PHYLIP - Phylogenetic Inference Package version 3.5.1. Seattle: Department of Genetics, University of Washington (available at http://evolution.genetics.washington.edu/ phylip/).

Fitch, W. M. (1971). Toward defining the course of evolution: minimum change for a specific tree topology. Syst Zool 20, 406-416.

Fitch, W. M. \& Margoliash, E. (1967). Construction of phylogenetic trees: a method based on mutation distances as estimated from cytochrome c sequences is of general applicability. Science 155, 279-284.

Goodfellow, M., Kim, S. B., Minnikin, D. E., Whitehead, D., Zhou, Z.-H. \& Mattinson-Rose, A. D. (2001). Amycolatopsis sacchari sp. nov., a moderately thermophilic actinomycete isolated from vegetable matter. Int J Syst Evol Microbiol 51, 187-193.

Groth, I., Schumann, P., Weiss, N., Martin, K. \& Rainey, F. A. (1996). Agrococcus jenensis gen. nov., sp. nov., a new genus of actinomycetes with diaminobutyric acid in the cell wall. Int J Syst Bacteriol 46, 234-239.

Groth, I., Schütze, B., Boettcher, T., Pullen, C. B., Rodriguez, C., Leistner, E. \& Goodfellow, M. (2003). Kitasatospora putterlickiae sp. nov., isolated from rhizosphere soil, transfer of Streptomyces kifunensis to the genus Kitasatospora as Kitasatospora kifunensis comb. nov., and emended description of Streptomyces aureofaciens Duggar 1948. Int J Syst Evol Microbiol 53, 2033-2040.

Groth, I., Tan, G. Y. A., Gonzales, J. M., Laiz, L., Carlsohn, M. R., Schütze, B., Wink, J. \& Goodfellow, M. (2007). Amycolatopsis nigrescens sp. nov., an actinomycete isolated from a Roman catacomb. Int J Syst Evol Microbiol 57, 513-519.

Hasegawa, T., Takizawa, M. \& Tanida, S. (1983). A rapid analysis for chemical grouping of aerobic actinomycetes. J Gen Appl Microbiol 29, 319-322.

Hayakawa, M. \& Nonomura, H. (1987). Humic acid-vitamin agar, a new medium for the selective isolation of soil actinomycetes. J Ferment Technol 65, 501-509.

Huang, Y., Pasciak, M., Liu, Z. H., Xie, Q. \& Gamian, A. (2004). Amycolatopsis palatopharyngis sp. nov., a potentially pathogenic actinomycete isolated from a human clinical source. Int J Syst Evol Microbiol 54, 359-363.

Jukes, T. H. \& Cantor, C. R. (1969). Evolution of protein molecules. In Mammalian Protein Metabolism, pp. 21-132. Edited by H. N. Munro. New York: Academic Press.

Kim, S. B. \& Goodfellow, M. (1999). Reclassification of Amycolatopsis rugosa Lechevalier et al. 1986 as Prauserella rugosa gen. nov., comb. nov. Int J Syst Bacteriol 49, 507-512.

Kim, B., Sahin, N., Tan, G. Y. A., Zakrewska-Czerwinska, J. \& Goodfellow, M. (2002). Amycolatopsis eurytherma sp. nov., a thermophilic actinomycete isolated from soil. Int J Syst Evol Microbiol 52, 889-894.

Kroppenstedt, R. M., Mayilraj, S., Wink, J. M., Kallow, W., Schumann, P., Secondini, C. \& Stackebrandt, E. (2005). Eight new species of the genus Micromonospora, Micromonospora citrea sp. nov., Micromonospora echinaurantiaca sp. nov., Micromonospora echinofusca sp. nov., Micromonospora fulviviridis sp. nov., Micromonospora inyonensis sp. nov., Micromonospora peucetia sp. nov., Micromonospora sagamiensis sp. nov., and Micromonospora viridifaciens sp. nov. Syst Appl Microbiol 28, 328-339.

Labeda, D. P., Donahue, J. M., Williams, N. M., Sells, S. F. \& Henton, M. M. (2003). Amycolatopsis kentuckyensis sp. nov., Amycolatopsis lexingtonensis sp. nov., and Amycolatopsis pretoriensis sp. nov., isolated from equine placentas. Int J Syst Evol Microbiol 53, 1601-1605.

Lechevalier, M. P. \& Lechevalier, H. A. (1970). Chemical composition as a criterion in the classification of aerobic actinomycetes. Int J Syst Bacteriol 20, 435-443.

Lechevalier, M. P., De Biévre, C. \& Lechevalier, H. A. (1977). Chemotaxonomy of aerobic actinomycetes: phopholipid composition. Biochem Syst Ecol 5, 249-260.

Lechevalier, M. P., Prauser, H., Labeda, D. P. \& Ruan, J.-S. (1986). Two new genera of nocardioform actinomycetes: Amycolata gen. nov. and Amycolatopsis gen. nov. Int J Syst Bacteriol 36, 29-37. 
Lee, S. D., Kinkel, L. L. \& Samac, D. A. (2006). Amycolatopsis minnesotensis sp. nov., isolated from a prairie soil. Int J Syst Evol Microbiol 56, 265-269.

Minnikin, D. E., Alshamaony, L. \& Goodfellow, M. (1975). Differentiation of Mycobacterium, Nocardia, and related taxa by thin-layer chromatographic analysis of whole-organism methanolysates. J Gen Microbiol 88, 200-204.

Minnikin, D. E., Collins, M. D. \& Goodfellow, M. (1979). Fatty acid and polar lipid composition in the classification of Cellulomonas, Oerskovia and related taxa. J Appl Bacteriol 47, 87-95.

Pospiech, A. \& Neumann, B. (1995). A versatile quick-prep of genomic DNA from gram-positive bacteria. Trends Genet 11, 217-218.

Prauser, H. \& Falta, R. (1968). Phagensensibilität, Zellwand-Zusammensetzung und Taxonomie von Actinomyceten. Z Allg Mikrobiol 8, 39-46 (in German).

Saintpierre-Bonaccio, D., Amir, H., Pineau, R., Tan, G. Y. A. \& Goodfellow, M. (2005). Amycolatopsis plumensis sp. nov., a novel bioactive actinomycete isolated from a New-Caledonian brown hypermagnesian ultramafic soil. Int J Syst Evol Microbiol 55, 2057-2061.

Saitou, N. \& Nei, M. (1987). The neighbour-joining method: a new method for constructing phylogenetic trees. Mol Biol Evol 4, 406-425.

Schön, R. \& Groth, I. (2006). Practical thin layer chromatography techniques for diaminopimelic acid and whole cell sugar analyses in the classification of environmental actinomycetes. J Basic Microbiol 46, 243-249.

Shirling, E. B. \& Gottlieb, D. (1966). Methods for characterization of Streptomyces species. Int J Syst Bacteriol 16, 313-340.

Stackebrandt, E., Rainey, F. A. \& Ward-Rainey, N. L. (1997). Proposal for a hierarchic system, Actinobacteria classis nov. Int J Syst Bacteriol 47, 479-491.

Takahashi, Y. (2001). Family Pseudonocardiaceae. In Identification Manual of Actinomycetes, pp. 227-239. Edited by The Society for Actinomycetes Japan. Tokyo: The Business Centre for Academic Societies.
Tan, G. Y. A., Robinson, S., Lacey, E. \& Goodfellow, M. (2006a). Amycolatopsis australiensis sp. nov., an actinomycete isolated from arid soils. Int J Syst Evol Microbiol 56, 2297-2301.

Tan, G. Y. A., Ward, A. C. \& Goodfellow, M. (2006b). Exploration of Amycolatopsis diversity in soil using genus-specific primers and novel selective media. Syst Appl Microbiol 29, 557-569.

Uchida, K. \& Aida, K. (1984). An improved method for the glycolate test for simple identification of acyl type of bacterial cell walls. J Gen Appl Microbiol 30, 131-134.

Van de Peer, Y. \& De Wachter, R. (1994). TREECON for Windows: a software package for the construction and drawing of evolutionary trees for the Microsoft Windows environment. Comput Appl Biosci 10, 569-570.

Wayne, L. G., Brenner, D. J., Colwell, R. R., Grimont, P. A. D., Kandler, O., Krichevsky, M. I., Moore, L. H., Moore, W. E. C., Murray, R. G. E. \& other authors (1987). International Committee on Systematic Bacteriology. Report of the ad hoc committee on reconciliation of approaches to bacterial systematics. Int $J$ Syst Bacteriol 37, 463-464.

Wink, J. M., Kroppenstedt, R. M., Ganguli, B. N., Nadkarni, S. R., Schumann, P., Seibert, G. \& Stackebrandt, E. (2003). Three new antibiotic producing species of the genus Amycolatopsis, Amycolatopsis balhimycina sp. nov., A. tolypomycina sp. nov., A. vancoresmycina sp. nov., and description of Amycolatopsis keratiniphila subsp. keratiniphila subsp. nov. and A. keratiniphila subsp. nogabecina subsp. nov. Syst Appl Microbiol 26, 38-46.

Wink, J., Gandhi, J., Kroppenstedt, R. M., Seibert, G., Sträubler, B., Schumann, P. \& Stackebrandt, E. (2004). Amycolatopsis decaplanina sp. nov., a novel member of the genus with unusual morphology. Int J Syst Evol Microbiol 54, 235-239.

Yassin, A. F., Haggenei, B., Budzikiewicz, H. \& Schaal, K. P. (1993). Fatty-acid and polar lipid-composition of the genus Amycolatopsis: application of fast-atom-bombardment mass-spectrometry to structure-analysis of underivatized phospholipids. Int J Syst Bacteriol 43, $414-420$. 